University for Business and Technology in Kosovo

UBT Knowledge Center

UBT International Conference

2015 UBT International Conference

Nov 7th, 9:00 AM - 5:00 PM

\title{
Testing the martingales property of daily exchange rate
}

\author{
Rozana Liko \\ University Ismail Qemali Vlora, rozanaliko86@gmail.com \\ Artion Kashuri \\ University Ismail Qemali Vlora, miftar.ramosaco@gmail.com \\ Miftar Ramosaco \\ University Ismail Qemali Vlora, artionkashuri@gmail.com
}

Follow this and additional works at: https://knowledgecenter.ubt-uni.net/conference

Part of the Business Commons

\section{Recommended Citation}

Liko, Rozana; Kashuri, Artion; and Ramosaco, Miftar, "Testing the martingales property of daily exchange rate" (2015). UBT International Conference. 17.

https://knowledgecenter.ubt-uni.net/conference/2015/all-events/17

This Event is brought to you for free and open access by the Publication and Journals at UBT Knowledge Center. It has been accepted for inclusion in UBT International Conference by an authorized administrator of UBT Knowledge Center. For more information, please contact knowledge.center@ubt-uni.net. 


\title{
Testing the martingales property of daily exchange rate
}

\author{
Rozana Liko ${ }^{1}$, Artion Kashuri² ${ }^{2}$, Miftar Ramosaco ${ }^{3}$ \\ 1,2,3Department of Mathematics, Faculty of Technic Sciences, \\ University "Ismail Qemali" Vlora, Albania \\ rozanaliko86@gmail.com ${ }^{1}$ \\ miftar.ramosaco@gmail.com², artionkashuri@gmail.com ${ }^{3}$
}

\begin{abstract}
The purpose of this paper is to test whether the Albanian exchange rate market is weak form efficient by studying the statistical behavior of daily Euro and USD exchange rate against Albanian Lekë, which are the most influential currency in Albania market, during the period January 05, 2010 - April 30, 2015. The study seeks to examine whether this currencies follow each a martingale. The unit root tests (individually and panel) and variation ratio test are used. The various analytical tests implemented in the study provide evidence of non-martingale property of exchange market in Albania.
\end{abstract}

Keywords: Martingale, Unit root test, Variation ratio test, Exchange rate, Weak form efficiency

\section{Introduction}

The purpose of this paper is to determine whether the foreign exchange market is weak form efficient by studying the statistical behavior of two daily foreign currencies against Lekë. The paper seeks to examine whether these currencies follow each a martingale. The Random Walk hypothesis states that a security market is efficient if security prices instantaneously and fully reflects all available information. According to the Random Walk hypothesis stock market prices evolve in a random pattern and can therefore not be predicted. Some requirement of efficiency are, the presence of a unit root process, the increments are random and uncorrelated, long term persistence of shocks etc. [1]. Especially, market efficiency implies zero serial correlations in exchange rate changes [2].

Numerous studies have been made on the behavior of exchange rates under the float. Since Lo and MacKinlay (1988) proposed a variance ratio (VR) test, this procedure has been widely used and has undergone many improvements for testing market efficiency and return predictability [3]. Meese and Rogoff (1983) have shown that the structural models of exchange rate determination not perform better than the random walk in out-of-sample forecasts [4]. Liu and He (1991) applied the variance ratio test for the martingale property on five major exchange rates vis-a-vis US dollar over the sample period from August 1974 to March 1989 and rejected the martingale property for German mark, Japanese yen and British pound, but failed to do so for Canadian dollar and French franc vis-a-vis US dollar for weekly exchange rates [4]. Ajayi and Karemera (1996) on South Asian foreign exchange markets rejected RWH but found that rejection were not robust to heteroscedasticity. Wu and Chen (1998) used panel unit root test to examine the stationary of forward premia and interest rate differentials for nine OECD countries and found evidence in support of the RWH [5]. Franch and Opong (2005) used Lo-MacKinlay variance ratio test and Wright's (2000) ranks and signs test to examine random walk in Euro exchange rate against ten currencies and rejected random walk for Canadian Dollar, Singapore Dollar, Newzeland Dollar, Swiss Franc and Norway Kroner [5].

The paper is organized as follows: In the second section describes the sample data and descriptive statistics. In the third section is given a short presentation of the methodology. In section fourth empirical results are analyzed. Section five conclusions. 


\section{Data}

The data consist of daily nominal exchange rate of two currencies, Euro and US Dollar (USD), against Albanian Lekë, which are the most influential currency in Albania. The time series cover the period from January 2010 to April 2015, e.i. 1344 observations for variables. The data set are obtained from Bank of Albania (http://www.bankofalbania.org/), which is the monetary authority of Albania. Bank of Albania applies a free fluctuation regime, which means that the currency is determined according to the foreign exchange markets. The series are logged and the returns are calculated as first differences of natural logs.
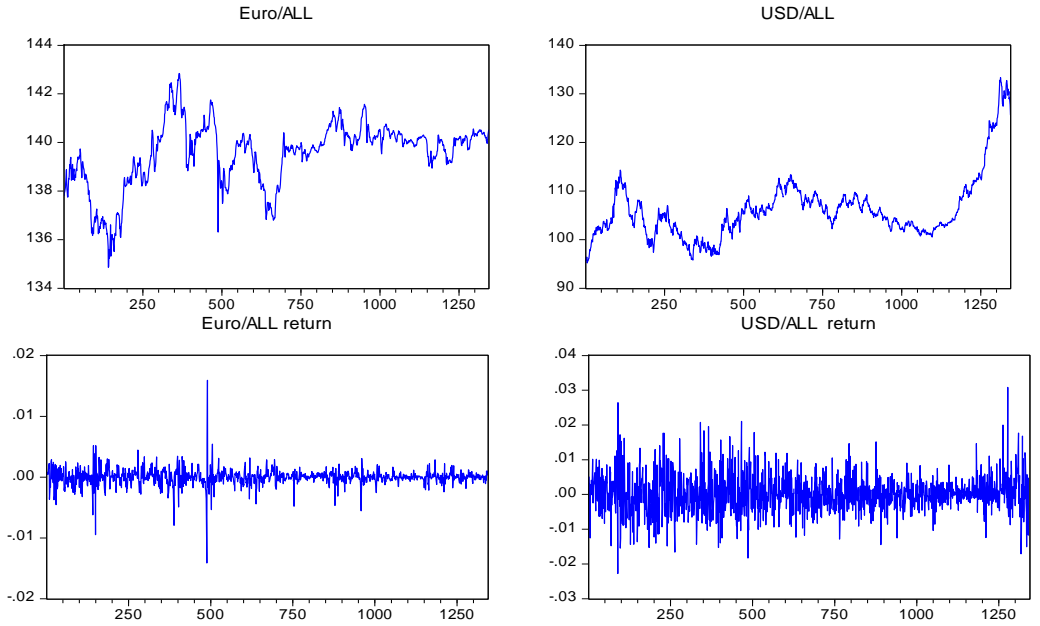

Fig. 1. Line graph of daily nominal exchange rate (above) and returns (below) of Euro/ALL and USD/ALL from 2010 to 2015

A visual inspection of the movements of currencies appears to be irregular and the mean returns are close to zero. All the series shows departures from Gaussian distribution. Jarque-Bera test reject the null hypothesis of normality at significant value 0.001 . The volatility of returns suggest for heteroscedastic nature of this series.

Table 1. Descriptive statistics of exchange rate and returns of Euro/ALL and USD/ALL from 2010

\begin{tabular}{|l|l|l|l|l|l|l|l|l|}
\hline Statistic & Mean & Median & Max. & Min. & $\begin{array}{l}\text { St. } \\
\text { Dev. }\end{array}$ & Skew & Kurt. & J-B \\
\hline Euro/ALL & 139.517 & 139.86 & 142.84 & 134.86 & 1.32 & -0.82 & 3.75 & $\begin{array}{l}182.35 \\
(0.000)\end{array}$ \\
\hline USD/ALL & 106.148 & 105.03 & 133.35 & 95.21 & 6.50 & 1.79 & 7.35 & $\begin{array}{l}1780.9 \\
(0.000)\end{array}$ \\
\hline $\begin{array}{l}\text { Euro/ALL } \\
\text { return }\end{array}$ & $1.46 \mathrm{e}^{-5}$ & $7.12 \mathrm{e}^{-5}$ & 0.0159 & 0.014 & 3 & -0.315 & 31.24 & $\begin{array}{l}44650.1 \\
(0.001)\end{array}$ \\
\hline $\begin{array}{l}\text { USD/ALL } \\
\text { return }\end{array}$ & 0.00019 & 0 & 0.030 & -0.022 & 0.005 & 0.398 & 5.044 & $\begin{array}{l}269.084 \\
(0.001)\end{array}$ \\
\hline
\end{tabular}

\section{Methodology}

Main concern of a market is to give equal chance to each investitor. In this paper we investigate weak form efficient where the market reflects all public information, and can described as a random walk process (or martingale). Some conditions of the weak form efficiency is the presence of a unit root and that increment are random and uncorrelated. 
Let $\left\{\mathbf{Y}_{\mathbf{t}}\right\}$ be a stochastic process, if $\Delta \mathbf{Y}_{\mathbf{t}}=\mathbf{Y}_{\mathbf{t}}-\mathbf{Y}_{\mathbf{t}-\mathbf{1}}=\boldsymbol{\alpha}+\boldsymbol{\varepsilon}_{\mathbf{t}}$, where $\boldsymbol{\alpha}$ is a constant and $\boldsymbol{\varepsilon}$ is the residue, such that $\mathbf{E}\left(\boldsymbol{\varepsilon}_{\mathbf{t}}\right)=\mathbf{0}, \mathbf{E}\left(\boldsymbol{\varepsilon}_{\mathbf{t}} \boldsymbol{\varepsilon}_{\mathbf{t}-\mathbf{1}}\right)=\mathbf{0}$, than $\left\{\mathbf{Y}_{\mathbf{t}}\right\}$ is said to be a Random Walk. If $\left\{\ln \left(\mathbf{Y}_{\mathbf{t}}\right)\right\}$ is a stochastic process, such as $\Delta \ln \left(\mathbf{Y}_{\mathrm{t}}\right)=\ln \left(\mathbf{Y}_{\mathrm{t}}\right)-\ln \left(\mathbf{Y}_{\mathrm{t}-\mathbf{1}}\right)=\boldsymbol{\alpha}+\boldsymbol{\varepsilon}_{\mathrm{t}}$, where $\boldsymbol{\alpha}$ is a constant and $\boldsymbol{\varepsilon}$ is the residue, such that $\mathbf{E}\left(\boldsymbol{\varepsilon}_{\mathrm{t}}\right)=\mathbf{0}, \mathbf{E}\left(\boldsymbol{\varepsilon}_{\mathrm{t}} \boldsymbol{\varepsilon}_{\mathbf{t}-\mathbf{1}}\right)=\mathbf{0}$, than $\left\{\mathbf{Y}_{\mathrm{t}}\right\}$ is said to be an Exponential Random Walk [6].

\subsection{L-B Q test}

Ljung-Box Q statistic is a modified variation of Box - Pierce Q statistic used to test the joint hypothesis that the autocorrelation coefficients up to lag $\mathrm{k}$ are equal to zero.

This test is defined as

\subsection{Run Test}

$$
\mathrm{Q}=\mathrm{N}(\mathrm{N}+2) \sum_{\mathrm{i}=1}^{\mathrm{k}} \frac{\rho_{\mathrm{i}}^{2}}{\mathrm{~N}-\mathrm{i}} \sim \chi^{2}(\mathrm{k})
$$

Run test (Wald Wolfowitz 1940) is a strong non-parametric test for detecting randomness of the series.

\subsection{Unit Root test}

In this study a battery of unit root tests are used. Panel Unit root tests: Levin, Lin \& Chu (2002), Breitung (2000) whose null hypothesis is a unit root; Hadri test whose null hypothesis is stationary. And individual unit root test as the well known ADF test (1979), Im, Pearan \& Shin (2003) test whose null hypothesis is a unit root.

\subsection{Variation ratio test}

Lo and MecKinly (1988) variation ratio test is the most used econometric test for the null hypothesis of a martingale, which is robust to heteroscedastic standard errors. If the time series follows a random walk then the variance should be proportional to the same interval, i.e.

$$
\operatorname{VR}(\mathrm{q})=\frac{\operatorname{Var}\left(\mathrm{Y}_{\mathrm{t}+\mathrm{k}}-\mathrm{Y}_{\mathrm{t}}\right) / \mathrm{k}}{\operatorname{Var}\left(\mathrm{Y}_{\mathrm{t}+1}-\mathrm{Y}_{\mathrm{t}}\right)}
$$

The statistical test which is robust under heteroscedasticity is given as follows

where

$$
\mathrm{Z}_{\mathrm{q}}^{*}=\frac{\mathrm{VR}(\mathrm{q})-1}{\sqrt{\sum_{\mathrm{j}=1}^{\mathrm{q}-1}\left[\frac{2(\mathrm{q}-\mathrm{j})}{\mathrm{q}}\right]^{2} \hat{\delta}(\mathrm{j})}} \sim \mathrm{N}(0,1)
$$

$$
\hat{\delta}(j)=\frac{\sum_{t=j+1}^{n q}\left(Y_{t}-Y_{t-1}-\hat{\mu}\right)\left(Y_{t-j}-Y_{t-j-1}-\hat{\mu}\right)^{2}}{\left[\sum_{t=1}^{n q}\left(Y_{t}-Y_{t-1}-\hat{\mu}\right)^{2}\right]}
$$

Chow and Denning (1993) extend the Variation ratio test by introducing multiple variation ratio test which is based on the maximum absolute value of individual variation ratio test

$$
\mathrm{Z}_{2}(\mathrm{q})=\max _{1 \leq \mathrm{i} \leq \mathrm{N}}\left|\mathrm{Z}_{\mathrm{q}_{\mathrm{i}}}^{*}\right|
$$

\section{Empirical results}

\subsection{Serial Correlation}

In Table 2 the results of Ljung-Box statistic on lag 10 are presented. As shown the null hypothesis of Euro/ALL return is rejected for $1 \%$ and $5 \%$ significant value. Different result is for USD/ALL return, 
the null hypothesis of zero serial correlation fails to reject. Applied run test on first differences of the logged data this test suggest the randomness of USD return, but not for Euro return.

Table 2. Serial correlation of daily return of EURO/ALL and USD/ALL

\begin{tabular}{|l|l|l|}
\hline & Euro/ALL & USD/ALL \\
\hline Ljung - Box stat. & $107.65(0.000)$ & $12.49(0.253)$ \\
\hline
\end{tabular}

Note: Actual p-values are reported in brackets

Table 3. Run test of $\Delta \log Y_{t}$

\begin{tabular}{|l|c|c|}
\hline & Mean & Median \\
\hline Euro/ALL & $5.326(0.000)$ & $5.326(0.000)$ \\
\hline USD/ALL & $0.176(0.860)$ & $0.082(0.934)$ \\
\hline
\end{tabular}

Note: z-statistic are reported and p-values in brackets

\subsection{Unit root}

One requirement of the weak form efficiency (or martingale) is a unit root in the data series. Results of application of panel unit root test are display in table 4. As shown all tests suggest the presence of unit root test in the level but not in first differences, except Hadri which suggest not stationarity in the level and stationarity on the first differences. This means that the series are integrated of order one, i.e I(1), and the returns are not integrated, i.e I(0).

Table 4. Unit root test of EURO/ALL and USD/ALL from January 2010 - April 2015.

\begin{tabular}{|c|c|c|c|c|c|c|c|}
\hline \multicolumn{8}{|c|}{ Assume individual unit root test } \\
\hline \multicolumn{4}{|c|}{ Level } & \multicolumn{4}{|c|}{ First differences } \\
\hline Methods & Stat. & Prob. & Observation & Stat. & Prob. & Observation & $\begin{array}{l}\text { Cross- } \\
\text { Sect. }\end{array}$ \\
\hline $\begin{array}{l}\text { ADF- Fisher } \\
\text { Chi-square }\end{array}$ & 7.264 & 0.122 & 2682 & 526.782 & 0.000 & 2680 & 2 \\
\hline $\begin{array}{l}\text { Im, Pearan \& } \\
\text { Shin }\end{array}$ & -0.801 & 0.211 & 2682 & -52.521 & 0.000 & 2680 & 2 \\
\hline $\begin{array}{l}\text { PP- Fisher } \\
\text { Chi-square }\end{array}$ & 6.825 & 0.145 & 2684 & 526.782 & 0.000 & 2681 & 2 \\
\hline \multicolumn{8}{|c|}{ Assume common unit root test } \\
\hline Methods & Stat. & Prob. & Observation & Stat. & Prob. & Observation & $\begin{array}{l}\text { Cross- } \\
\text { Sect. }\end{array}$ \\
\hline $\begin{array}{l}\text { Levin, Lin \& } \\
\text { Chu t* }\end{array}$ & 0.597 & 0.724 & 2682 & -80.847 & 0.000 & 2680 & 2 \\
\hline Hadri & 6.04662 & 0.000 & 2687 & -0.224 & 0.589 & 2684 & 2 \\
\hline Breitung t-stat & -0.564 & 0.286 & 2680 & -23.023 & 0.000 & 2678 & 2 \\
\hline
\end{tabular}

\subsection{Variation ratio test}

To examine the correlation of increment the variation ratio and multiple variation ratio tests are employed and the results are presented in Table 5. The joint variation ratio test reject the null hypothesis of martingale for the Euro/ALL with p-value 0.003 , but fails to reject the null hypothesis for USD/ALL. All individual variation ratio tests are insignificantly different from 1, which means that there is no significant serial correlation, except Euro for which the results are mixed. 
Table 5. Variation ratio test for Exponential Random Walk of $\log (E U R O / A L L)$ and $\log (\mathrm{USD} / \mathrm{ALL})$ during the period January 2010 - April 2015.

\begin{tabular}{|c|c|c|c|c|c|c|}
\hline \multirow{2}{*}{$\begin{array}{l}\text { Chow-Denning } \\
\text { ratio test }\end{array}$} & \multirow{2}{*}{ Joint Variation } & \multicolumn{5}{|c|}{ Individual Variation ratio test } \\
\hline & & Period & 2 & 4 & 8 & 16 \\
\hline \multicolumn{2}{|c|}{$H_{0}: \log ($ Euro/ALL) is a martingale } & Var.Ratio & 1.257 & 1.288 & 1.228 & 1.059 \\
\hline $\operatorname{Max}|z|$ & 3.341 & Std. Error & 0.077 & 0.157 & 0.223 & 0.275 \\
\hline df & 1343 & z-statistic & 3.341 & 1.834 & 1.019 & 0.215 \\
\hline Prob. & 0.0033 & Prob. & 0.008 & 0.06 & 0.308 & 0.829 \\
\hline \multirow{2}{*}{\multicolumn{2}{|c|}{$\begin{array}{l}\text { Chow-Denning Joint Variation } \\
\text { ratio test }\end{array}$}} & \multicolumn{5}{|c|}{ Individual Variation ratio test } \\
\hline & & Period & 2 & 4 & 8 & 16 \\
\hline \multicolumn{2}{|c|}{$H_{0}: \log (\mathrm{USD} / \mathrm{ALL})$ is a martingale } & Var.Ratio & 1.008 & 1.012 & 1.028 & 1.106 \\
\hline $\operatorname{Max}|z|$ & 0.751 & Std. Error & 0.033 & 0.061 & 0.095 & 0.141 \\
\hline df & 1341 & z-statistic & 0.242 & 0.201 & 0.294 & 0.751 \\
\hline Prob. & 0.916 & Prob. & 0.808 & 0.840 & 0.768 & 0.0452 \\
\hline
\end{tabular}

\section{Conclusions}

The purpose of this study is to examine the weak form efficiency (informational efficiency) of exchange market in Albania. Two currency are selected, daily nominal Euro/ALL and USD/ALL during the period January 05, 2010 - April 30, 2015.

The panel unit root test applied on the series suggest the presence of only one unit root which in consistent with the martingale hypothesis.

Variation ratio test more than one suggest positive correlation of returns. Multiple variation ratio test rejects the martingale hypothesis for Euro return but fails to reject this hypothesis for USD return.

\section{References}

1. Azar S. A.: Martingales in Daily Foreign Exchange Rates: Evidence from Six Currencies against the Lebanese Pound, Applied Economics and Finance, Vol. 1, No. 1, (May 2014)

2. Lee H. Y., Sodoikhuu K.: Efficiency Tests in Foreign Exchange Market. International Journal of Economics and Financial Issues. Vol. 2, No. 2( 2012) 216-224

3. Phillips P. C. B., JIN S.: Testing the Martingale Hypothesis. American Statistical Association Journal of Business \& Economic Statistics. Vol. 32, No. 4 (October 2014)

DOI: $10.1080 / 07350015.2014 .908780$

4. Yilmaz K.: Martingale Property of Exchange Rates and Central Bank Interventions. Social science research network, June 2001, http://ssrn.com/abstract $=280888$

5. Vats A., Kamaiah B.: Is There a Random Walk in Indian Foreign Exchange Market?. International Journal of Economics and Finance. Vol. 3, No. 6 (November 2011) 157-165

6. Rufino C. C.: Martingale In Floating Asean+3 Currencies. DLSU Bisness \& Economics Review. Vol.23 No. 2 (2014) 65-79

7. Yaffee R.: Introduction to time series analysis and forecasting with application of SAS and SPSS; Academic Press, INC 2000

8. Kirchgässner G., Wolters J., Hassler U.: Introduction to modern time series Analysis. 2-nd edn. Springer-Verlag, Berlin Heidelberg (2013). 